\title{
STUDI AWAL ESTIMASI DOSIS INTERNAL 99mTC-MDP HASIL PRODUKSI PSTNT-BATAN PADA MANUSIA UNTUK DETEKSI METASTASIS DAN INFLAMASI TULANG BERBASIS UJI BIODISTRIBUSI HEWAN MODEL MENCIT
}

\section{PRELIMINARY STUDY ON INTERNAL DOSE ESTIMATION OF 99MTC-MDP PRODUCED BY PSTNT-BATAN IN HUMAN FOR DETECTION OF HUMAN BONE METASTASIS AND INFLAMMATION BASED ON THE BIODISTRIBUTION ANIMAL MODEL MICE}

\author{
A. Isnaini Nur Islami' ${ }^{1}$, B. Nur Rahmah Hidayatiं ${ }^{2}$, C. Teguh Hafiz Ambar Wibawa ${ }^{3}$, D. Iswahyudi ${ }^{3}$, E. Isti \\ Daruwati ${ }^{3}$, F. Moch Nurul Subkhi ${ }^{1}$ \\ ${ }^{1}$ Fakultas Sains dan Teknologi -UIN Sunan Gunung Djati Bandung 40416, Indonesia \\ ${ }^{2}$ Pusat Teknologi Keselamatan dan Metrologi Radiasi - BATAN Jakarta 12440, Indonesia \\ 3Pusat Sains dan Teknologi Nuklir Terapan - BATAN Bandung 40132, Indonesia \\ E-mail : isnaininurislami@gmail.com
}

Diterima 20 Januari 2019, diterima dalam bentuk perbaikan 25 Agustus 2019, disetujui 14 Oktober 2019

\begin{abstract}
ABSTRAK
STUDI AWAL ESTIMASI DOSIS INTERNAL 99mTC-MDP HASIL PRODUKSI PSTNT-BATAN PADA MANUSIA UNTUK DETEKSI METASTASIS DAN INFLAMASI TULANG BERBASIS UJI BIODISTRIBUSI HEWAN MODEL MENCIT. Kanker adalah sel abnormal yang dapat menyebar sampai ke tulang. Pemeriksaan dapat dilakukan dengan bone-scan menggunakan radiofarmaka. PSTNT-BATAN Bandung melakukan penelitian radiofarmaka penyidik tulang yaitu MDP yang dapat ditandai dengan radionuklida teknesium-99m. Penelitian ini bertujuan memperoleh estimasi dosis internal radiofarmaka ${ }^{99 m} \mathrm{mc}-\mathrm{MDP}$ sebagai penyidik metastasis dan inflamasi tulang untuk manusia berdasarkan biodistribusi radiofarmaka ${ }^{99 m} T c-M D P$ produksi PSTNT-BATAN. Metode penelitian ini, uji biodistribusi dari penandaan MDP dengan teknesium-99m dengan interval waktu 2,4,6, dan 24 jam setelah penyuntikan melalui intravena ekor pada 12 hewan model mencit normal dengan dosis injeksi 5,44 MBq tiap mencit dengan kemurnian 98,49\% $\pm 25,37$. Hasil uji biodistribusi didapatkan persentase dosis injeksi per gram organ hewan yang dikonversi menjadi persentase dosis injeksi per gram organ manusia yang diinput pada software OLINDA/EXM untuk mendapatkan residence time dan estimasi dosis internal. Hasil estimasi dosis menggunakan OLINDA/EXM diperoleh nilai total estimasi dosis

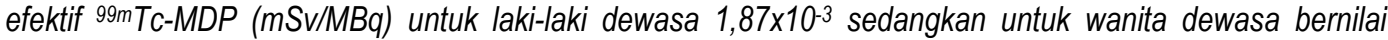
2,24x10-3. Hasil estimasi dosis radiofarmaka ${ }^{99 m}$ Tc-MDP produksi PSTNT-BATAN ini dapat digunakan sebagai panduan dosis organ pada saat akan diinjeksikan pada manusia.
\end{abstract}

Kata kunci: ${ }^{99 m} T c-M D P$, uji biodistribusi, estimasi dosis internal.

\section{ABSTRACT}

PRELIMINARY STUDY ON INTERNAL DOSE ESTIMATION OF 99mTC-MDP PRODUCED BY PSTNTBATAN IN HUMAN FOR DETECTION OF HUMAN BONE METASTASIS AND INFLAMMATION BASED ON THE BIODISTRIBUTION ANIMAL MODEL MICE. Cancer is the abnormal cells that can spread to the bone.Examination can be done with bone scan. PSTNT-BATAN Bandung conducted bone investigator radiopharmaceutical research with technetium- $99 \mathrm{~m}$ radionuclides by MDP labelling. This study aims to obtain an estimation of internal dose of ${ }^{99 m} \mathrm{mc}-\mathrm{MDP}$ radiopharmaceutical as an investigator metastasis and bone inflammation to humans based the biodistribution of ${ }^{99 m}$ Tc-MDP radiopharmaceutical PSTNT-BATAN production. This research method, biodistribution test of MDP labeling with technetium-99m with intervals of 2,4,6, and 24 hours after injection through intravenous tail on 12 normal mice at a dose injection $5.44 \mathrm{MBq}$ per mice with a purity is $98.49 \% \pm 25,37$. The biodistribution test result obtained percentage pergram injection dose animal organs that converted into percentages injection dose pergram human organs as value input to the software OLINDA/EXM to get a residence-time and internal dose estimation. The results of the dose estimation using OLINDA/EXM obtained a total value estimated effective dose of ${ }^{99 m} T \mathrm{c}-M D P$ (mSV/MBq) for adult males $1,87 \times 10^{-3}$ and for adult women is $2,24 \times 10^{-3}$. Results a dose estimation of ${ }^{99 m} \mathrm{mc}-M D P$ radiopharmaceutical PSTNT-BATAN production can be used as a guide when the organ doses to be injected in humans.

Keywords: ${ }^{99 m} T c-M D P$, biodistribution test, internal dose estimation 
Jurnal Iptek Nuklir Ganendra

Ganendra Journal of Nuclear Science and Technology

Vol. 22 No. 2, Juli 2019: 85-93

\section{PENDAHULUAN}

Denyebab kematian utama manusia yang terjadi di seluruh dunia adalah salah satunya penyakit kanker. Kanker merupakan penyakit yang timbul akibat pertumbuhan sel jaringan yang tidak normal. Pada tahun 2012, sekitar 8,2 juta kematian disebabkan oleh kanker. Jenis kanker penyebab kematian tertinggi tiap tahunnya adalah kanker paru-paru, prostat, hati, perut, kolorektal, dan kanker payudara [1]. Sel kanker dapat menyebar ke bagian organorgan lainnya, dimana hal itu disebut metastasis. Sel kanker bermetastasis melalui darah dan getah bening akan menempel pada tulang melalui celah endothelial-specific bone marrow [2]. Dalam beberapa kasus tulang menjadi objek yang sering ditemukan pada metastasis dari induk kanker seperti kanker prostat dan payudara. Misalnya kanker prostat yang penyebarannya tertinggi sampai mencapai $70 \%$ pengidap kanker prostat mengalami metastasis ke tulang karena adanya pleksus pembuluh darah vena. Metastasis ke tulang akan menimbulkan rasa nyeri sampai dengan kelumpuhan sebagian atau hemiparese [3]. Apabila kanker sudah bermetastasis ke organ yang ada di sekitarnya kemudian ke tulang melalui aliran darah, maka hal itu sangat serius dan mempengaruhi meningkatnya stadium kanker induk. Metastasis ke organ tulang juga dapat mengakibatkan inflamasi seperti nyeri sendi (architis), patah tulang (fraktura), osteositis, dan sebagainya walaupun inflamasi juga dapat hadir karena faktor genetik [4].

Tulang normal akan sistematis melakukan pembentukan dan perbaikan tulang yang dipengaruhi oleh osteoklas (resorpsi tulang) dan osteoblast (pembentuk tulang). Ketika tulang tua akan rusak maka akan terbentuk tulang baru sehingga tulang tetap sehat dan kuat. Sedangkan pada tulang yang mengalami metastasis ada dua kemungkinan. Kemungkinan pertama adalah tulang tua akan rusak namun tulang baru tidak terbentuk dan kedua adalah tulang tua belum rusak namun sudah terbentuk tulang baru [2]. Efek metastatis pada tulang merupakan gangguan dalam struktur tulang, sistem hematopoetic, dan metabolisme mineral osteolitik [5]. Hal tersebut mengakibatkan tulang rentan mengalami inflamasi tulang. Metastasis dan inflamasi dapat dideteksi salah satunya dengan menggunakan metode bone scintigraphy yang merupakan metode diagnostik dengan radiofarmaka [6]. Hal tersebut sangat penting untuk mengetahui metastasis ke tulang karena berguna untuk mengetahui tingkat keparahan kanker dan tingkat harapan hidup dari pasien kanker. Dimana radiofarmaka tersebut dihasilkan dari campuran antara kit farmaka dengan radioisotop yang memiliki waktu paruh tertentu. Pemeriksaan bone scan, radionuklida yang digunakan adalah ${ }^{99 \mathrm{mTC}}$ (teknesium 99 metastabil). $99 \mathrm{mTc}$ ini merupakan radioisotop yang memancarkan gamma murni dengan energi $140 \mathrm{keV}$ dengan waktu paruh 6 jam sehingga ketika ${ }^{99 \mathrm{mT}} \mathrm{Tc}$ berada dalam tubuh pasien tidak terlalu lama dan ${ }^{99 \mathrm{mT}} \mathrm{c}$ juga akan disekresi dan dieksresi dari tubuh melalui urin dan tinja. Kemudian kit farmaka adalah bahan obat yang dicampur dengan radioisotop yang menjadi zat pembawa untuk mencapai organ target yang dikehendaki [7]. Contoh kit farmaka yang biasa digunakan untuk mendeteksi metastasis ke organ tulang adalah MDP. Kit farmaka MDP atau methylenediphosphonate merupakan senyawa golongan fosfonat yang sering digunakan sebagai zat pembawa untuk penyidik tulang. MDP yang ditandai dengan 99mTc berfungsi sebagai radiofarmaka penyidik tulang. Sampai sekarang penyidik tulang menggunakan ${ }^{99 \mathrm{mTC}} \mathrm{MDP}$ tetap digunakan sebagai alat diagnostik paling sensitif untuk pencitraan tulang [8].

Terkait dengan penelitian sebelumnya yang dilakukan oleh Rizki Juwita dkk [9] yang hanya menguji radiofarmaka 99m-Tc-MDP sampai dengan uji biodistribusi, maka kit farmaka MDP hasil produksi dari PSTNT BATAN yang ditandai dengan ${ }^{99 m-T c}$ perlu dilakukan kajian estimasi dosis internal untuk mendukung aspek keamanan dan keselamatan produk radiofarmaka yang dihasilkan PSTNT. Kajian tersebut melalui uji praklinis pada mencit sebelum diinjeksikan pada uji klinis ke manusia. Pengkajian estimasi dosis dapat dilakukan melalui pengkajian uji biodistribusi.

Pengkajian uji biodistribusi dari radiofarmaka 99m-Tc-MDP untuk mengetahui tempat dan waktu penyebaran setelah injeksi. Uji biodistribusi dilakukan dengan mengambil organ-organ pada mencit melalui pembedahan untuk diamati proses biodistribusi dengan waktu tertentu. Hasil uji biodistribusi pada hewan coba mencit dapat digunakan untuk memprediksikan dosis internal radiasi pada pasien dengan melakukan perhitungan persentase dosis injeksi per gram organ hewan yang dikonversi menjadi persentase dosis injeksi per gram organ manusia berdasarkan data referensi ICRP [10]. Hasil perhitungan tersebut dapat digunakan untuk menentukan estimasi dosis internal dan juga kualitas pencitraan organ. 
Studi Awal Estimasi Dosis Internal 99mTc-MDP Hasil Produksi Pstnt-Batan Pada Manusia Untuk Deteksi Metastasis dan Inflamasi Tulang Berbasis Uji Biodistribusi Hewan Model Mencit (Isnaini Nur Islami, dkk.)

\section{METODOLOGI}

Alat yang digunakan dalam penelitian ini adalah SCA (Single Channel Analyzer) digunakan untuk pencacah radioaktivitas, dose calibrator, oven, vial, seperangkat alat bedah, timbangan, dan syringe. Dan bahan yang digunakan adalah kit kering radiofarmaka 99mTc-MDP produksi PSTNT-BATAN Bandung, aseton kering, larutan $\mathrm{NaCl}$, kertas Whatman-3MM untuk kromatografi, dan larutan chloroform untuk anastesi. Kemudian hewan yang akan digunakan pada penelitian ini adalah mencit jantan (Mus musculus) dengan berat 30-40 g.

\subsection{Penyiapan kit radiofarmaka 99mTc-MDP}

Sebanyak 2,5 $\mathrm{mL}$ larutan radioisotop $\mathrm{Na}^{99 \mathrm{mTCO} 4}$ didapatkan dari proses elusi oleh natrium klorida pada generator ${ }^{99} \mathrm{Mo}$ dengan aktivitas $2,46 \mathrm{mCi}$ dimasukkan ke dalam vial yang berisi kit kering MDP yang berada di dalam container $\mathrm{Pb}$. Kemudian larutan tersebut dikocok sempurna menjadi larutan homogen ${ }^{99 m T c-M D P}$ dan diinkubasi pada suhu kamar selama 30 menit.

Kemudian dilakukan pengujian kemurnian dan pemisahan ${ }^{99 m} \mathrm{Tc}$ dan pengotornya dengan menggunakan metode kromatografi, dimana 99mTc-MDP diteteskan dititik 0 pada kertas Whatman-3MM (titik -1 sampai 8), lalu kertas tersebut dicelupkan pada eluen $\mathrm{NaCl}$ dan aseton kering. Setelah itu dicacah per $\mathrm{cm}$ kertas Whatman-3MM

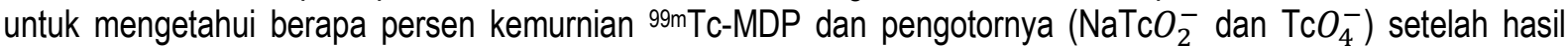
cacahan tersebut dihitung pada MS Excel.

\subsection{Uji Biodistribusi}

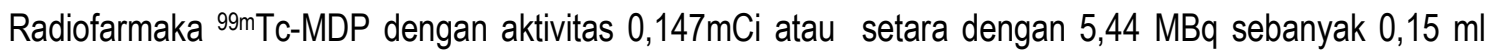
diinjeksikan pada mencit melalui intravena ekor kemudian dibedah dan diambil organ-organ sesuai dengan interval waktu yang ditentukan yaitu jam ke-2, 4, 6, dan 24. Dan untuk tiap interval waktu akan dibedah 3 ekor mencit. Organ-organ berupa kulit, otot, darah, usus, hati, lambung, limpa, ginjal, jantung, paru-paru, tulang, otak dan kandung kemih. Kemudian organ-organ tersebut ditimbang dan dicacah dengan menggunakan pencacah SCA (Single Channel Analyzer). Setelah itu hasil pencacahan dihitung untuk mendapatkan persentase dosis injeksi per gram organ $(\% \mathrm{ID} / \mathrm{g})$ mencit dengan persamaan [9] :

$$
\% \frac{I D}{g}=\frac{\text { cacahan per gram organ }}{\text { cacahan dosis yang diinjeksikan }} \times 100 \ldots \ldots . .
$$

\subsection{Estimasi Dosis Internal Menggunakan Software OLINDA/EXM}

Nilai persentase dosis injeksi per gram organ hewan yang telah didapatkan, selanjutnya dikonversi menjadi persentase dosis injeksi per gram organ manusia dengan persamaan [10][11] :

$$
\% \frac{I D}{g} \text { human }=\left[\left(\frac{\% I D}{g \text { organ }}\right)_{\text {animal }} x\left(k g_{T B-w e i g h t}\right)_{\text {animal }}\right] x\left(\frac{\text { gorgan }}{k g \text { TB-weight }}\right)_{\text {human }} \ldots \ldots . .
$$

Data referensi manusia yang digunakan adalah data dari referensi ICRP dengan berat manusia $60 \mathrm{~kg}$. Setelah didapatkan \%ID/g organ manusia maka diinput pada software OLINDA/EXM untuk mendapatkan residence time yang berasal dari integral grafik aktivitas radiofarmaka terhadap interval waktu, kemudian akan didapatkan estimasi dosis internal total dan tiap organnya.

\section{HASIL DAN PEMBAHASAN}

Kemurnian radiofarmaka 99mTC-MDP dilakukan dengan metode kromatografi pada tanggal 12 Juli 2018. Metode kromatografi ini menggunakan eluen $\mathrm{NaCl}$ dan aseton kering sebagai fase gerak dan kertas Whatman-

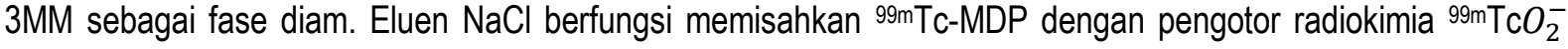

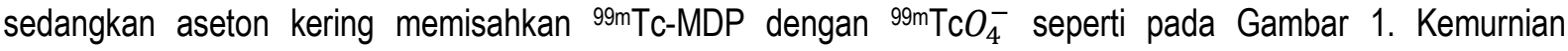


radiofarmaka 99mTc-MDP didapatkan hasil $98,49 \% \pm 25,37$. Hal tersebut telah sesuai dengan syarat pengujian radiofarmaka melalui uji biodistribusi dengan kemurnian $>90 \%$ [12].

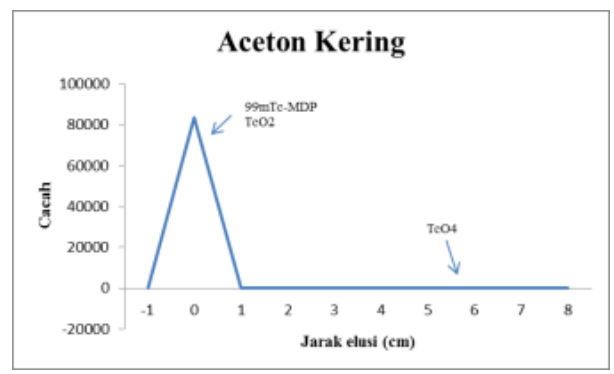

(a)

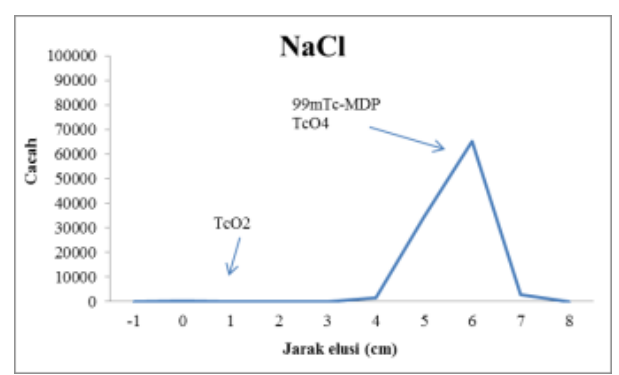

(b)

Gambar 1. Uji kemurnian ${ }^{99 m} \mathrm{Tc}-\mathrm{MDP}$ dengan metode kromatograf (a) Pemisahan pengotor $\mathrm{TcO}_{4}$ dengan aseton kering. (b) Pemisahan pengotor $\mathrm{TcO}_{2}$ dengan eluen $\mathrm{NaCl}$.

Berdasarkan uji biodistribusi yang dilakukan pada tanggal 12-13 Juli 2018 dengan pembedahan mencit didapatkan perhitungan persentase dosis injeksi per gram (\% ID/g) organ hewan dengan perhitungan pada Persamaan (1) dengan akumulasi tertinggi pada organ target yaitu tulang dengan $11,85 \% ; 24,53 \% ; 13,51 \% ; 6,93 \%$ berturut pada waktu 2, 4, 6, dan 24 jam pasca injeksi. Mekanisme uptake tulang terhadap 99mTc-MDP pada 4 jam menunjukan nilai tertinggi yang disebabkan oleh metabolisme reaksi tulang dengan MDP dan sekaligus reabsorpsi [13]. Kemudian terjadi penurunan yang dapat diakibatkan radiofarmaka mulai dieksresikan. Organ yang berakumulasi tinggi pula yaitu kandung kemih mengindikasikan bahwa urin yang mengandung radiofarmaka ${ }^{99 m T c-}$ MDP tersimpan sementara dan keluar dari tubuh melalui uretra. Terlihat pula akumulasi tertinggi selanjutnya adalah ginjal yang mengindikasi jalannya proses eksresi yaitu proses penyaringan darah yang mengandung radiofarmaka 99mTc-MDP yang selanjutnya darah tersebut akan mengalami tahap reabsorpsi sampai augmentasi menjadi urin. Dan akumulasi terlihat juga pada hati yang mengindikasikan radiofarmaka diekresikan dalam bentuk feses. Proses uji biodistribusi pada penelitian ini telah sesuai dengan yang dikatakan pada penelitian Rizky dkk [9] bahwa radiofarmaka ${ }^{99 m T C-M D P ~ m e m e n u h i ~ s y a r a t ~ r a d i o f a r m a k a ~ s e b a g a i ~ p e n y i d i k ~ y a i t u ~ m e m i l i k i ~ k e c e p a t a n ~ p r o s e s ~ e k s r e s i ~}$ dari tubuh yang tinggi. Kemudian proses bone scan pada umumnya dilakukan 3 jam setelah injeksi radiofarmaka Tc-MDP dengan kamera gamma, sehingga tingginya distribusi aktivasi radiofarmaka di tulang pada 4 jam setelah injeksi dilihat pada Gambar 3 menunjukan pencitraan yang cukup baik [14][15] .

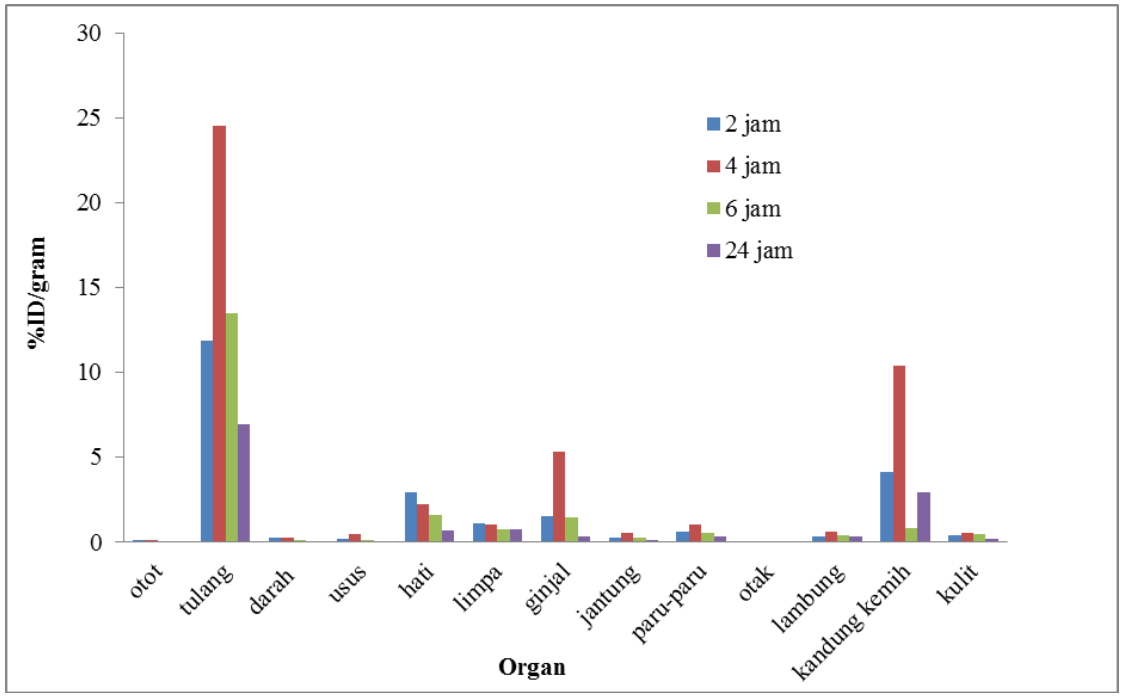

Gambar 2. \% ID/g organ mencit pada interval waktu tertentu hasil dari uji biodistribusi. 
Studi Awal Estimasi Dosis Internal 99mTc-MDP Hasil Produksi Pstnt-Batan Pada Manusia Untuk Deteksi Metastasis dan Inflamasi Tulang Berbasis Uji Biodistribusi Hewan Model Mencit (Isnaini Nur Islami, dkk.)

Metode ekstrapolasi ini telah banyak dilakukan pada studi-studi radiofarmaka baru seperti yang dilakukan Nur Rahmah dkk [17], H. Rezaeejam dkk [18], H. Ranjbar dkk [19], dan S. Shanehsazzadeh dkk [20]. Penimbunan dosis injeksi radiofarmaka ${ }^{99 m T c-M D P}$ per gram organ manusia terakumulasi pada organ target yaitu tulang ditunjukkan pada Gambar 3 didapatkan 26,79\%; 52,83\%; 30,31\%; dan 14,46\% pada waktu berturut-turut 2, 4, 6, dan 24 jam. Akumulasi tertinggi setelah organ target adalah hati, otot, dan ginjal seperti pada Gambar 3. Akumulasi tinggi di hati dan ginjal tersebut menggambarkan bahwa radiofarmaka 99mTc-MDP terjadi proses eksresi dalam bentuk urin dan tinja. Akumulasi tinggi di otot menggambarkan adanya kecacatan mineral karena menurut Steen Bach dan Ole W Krogssgaard [21] bahwa difosfonat akan efektif terdistribusi pada organ atau jaringan yang cacat mineralisasinya. Juga bisa dikarenakan otot tersebut menerima radiasi dari target yang menjadi sumber seperti tulang, dinding lambung, usus, kandung kemih, dan organ dalam lainnya.

Diperoleh pula nilai residence time radiofarmaka ${ }^{99 m T C-M D P}$ pada Tabel 1. Residence time pada percobaan ini digunakan untuk mendapatkan nilai estimasi dosis internal pada software OLINDA/EXM dengan memasukan nilai \% ID/g organ manusia dan hewan dan interval waktu yang dilakukan pada saat uji biodistribusi. Nilai residence time didapatkan dengan mengintegralkan luas kurva aktivitas terhadap waktu. Dalam kasus ini, OLINDA/EXM menyediakan perhitungan residence time. Waktu tinggal radiofarmaka 99mTc-MDP yang terakumulasi pada tiap organ dapat dilihat pada Tabel 1. Beberapa residence time organ pada hewan terlihat lebih lama dibandingkan pada manusia, kecuali organ otot, tulang, paru-paru, dan otak. Hal tersebut karena residence time sangat dipengaruhi oleh nilai \% ID/g organ. Semakin besar nilai \% ID/g organ maka residence time radiofarmaka pada organ pun lebih lama. Nilai residence time pada Tabel 1 digunakan sebagai faktor konversi jika radiofarmaka akan diinjeksikan kepada manusia [17].

Estimasi dosis internal untuk kit radiofarmaka ${ }^{99 \mathrm{mTC}} \mathrm{TDDP}$ berdasarkan hasil uji biodistribusi pada mencit dilakukan melalui software OLINDA/EXM, yang hasilnya seperti ditunjukan pada Tabel 2. dengan dosis estimasi tertinggi untuk laki-laki dewasa yaitu sumsum merah $7,68 \times 10^{-4} \mathrm{mSv} / \mathrm{MBq}$, sel esteogenik $3,12 \times 10^{-4} \mathrm{mSv} / \mathrm{MBq}$, usus $1,41 \times 10^{-4} \mathrm{mSv} / \mathrm{MBq}$, paru-paru $1,37 \times 10^{-4} \mathrm{mSv} / \mathrm{MBq}$, dan hati $1,18 \times 10^{-4} \mathrm{mSv} / \mathrm{MBq}$. Sedangkan untuk wanita dewasa yaitu sumsum merah $8,42 \times 10^{-4} \mathrm{mSv} / \mathrm{MBq}$, sel osteogenik $4,08 \times 10^{-4} \mathrm{mSv} / \mathrm{MBq}$, paru-paru $1,77 \times 10^{-4}$ $\mathrm{mSv} / \mathrm{MBq}$, usus $1,70 \times 10^{-4} \mathrm{mSv} / \mathrm{MBq}$, dan hati $1,51 \times 10^{-4} \mathrm{mSv} / \mathrm{MBq}$. Dosis efektif total untuk laki-laki dewasa adalah $1,87 \times 10^{-3} \mathrm{mSv} / \mathrm{MBq}$ dan wanita dewasa $2,24 \times 10^{-3} \mathrm{mSv} / \mathrm{MBq}$. Perbedaan dosis tiap gender dapat dikarenakan massa atau berat dari laki-laki atau wanita dewasa berbeda sehingga dosis yang diterima pun berbeda.

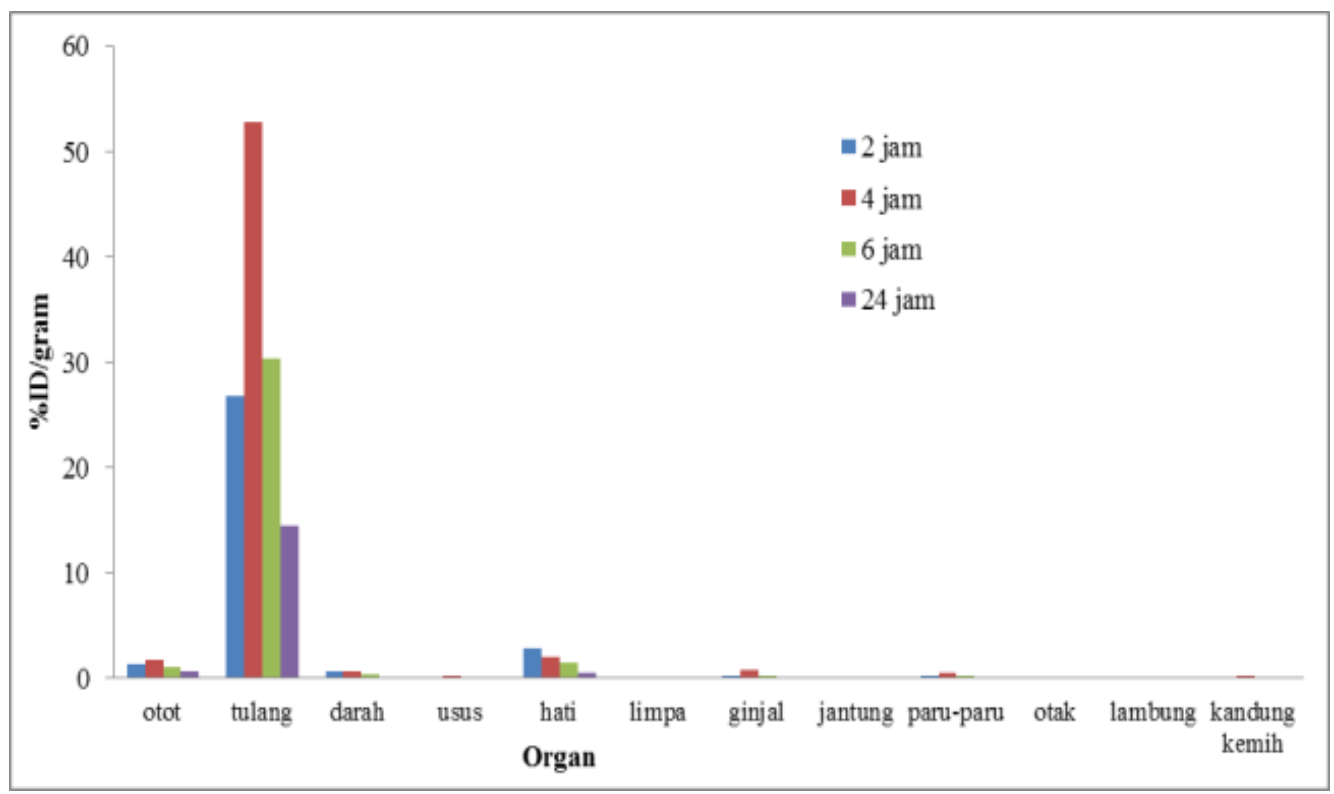

Gambar 3. \% ID/g organ manusia pada interval waktu tertentu berdasarkan konversi dari \%ID/g organ hewan. 
Jurnal Iptek Nuklir Ganendra

Ganendra Journal of Nuclear Science and Technology

Vol. 22 No. 2, Juli 2019: 85-93

Tabel 1. Nilai residence time radiofarmaka ${ }^{99 m T c-M D P ~ u n t u k ~ t i a p ~ o r g a n ~ p a d a ~ m a n u s i a ~ d a n ~ h e w a n ~}$

\begin{tabular}{lrr}
\hline \multicolumn{1}{c}{ Organ } & $\begin{array}{c}\text { Residence } \\
\text { Time } \\
\text { human(hr) }\end{array}$ & $\begin{array}{r}\text { Residence } \\
\text { time hewan } \\
(\mathrm{hr})\end{array}$ \\
\hline Otot & $1,06 \times 10^{-1}$ & $8,54 \times 10^{-3}$ \\
Tulang & 2,73 & $\begin{array}{r}1,25 \\
\text { Usus }\end{array}$ \\
Hati & $8,61 \times 10^{-3}$ & $1,96 \times 10^{-2}$ \\
Limpa & $1,58 \times 10^{-1}$ & $1,69 \times 10^{-1}$ \\
Ginjal & $7,13 \times 10^{-3}$ & $8,10 \times 10^{-2}$ \\
Jantung & $3,09 \times 10^{-2}$ & $1,94 \times 10^{-1}$ \\
paru-paru & $4,44 \times 10^{-3}$ & $2,79 \times 10^{-2}$ \\
Otak & $2,45 \times 10^{-2}$ & $5,64 \times 10^{-2}$ \\
Lambung & $1,78 \times 10^{-3}$ & $2,47 \times 10^{-3}$ \\
Kandung kemih & $2,14 \times 10^{-3}$ & $3,74 \times 10^{-2}$ \\
\hline
\end{tabular}

Pada Tabel 2 dapat dilihat bahwa dosis yang terbesar adalah sumsum merah, Menurut Enrico Napitupulu dkk [22] bahwa metastasis pada tulang paling banyak ditemukan di sumsum tulang merah pada tulang aksial. Hal tersebut menggambarkan bahwa tulang berperan tidak hanya menjadi target namun juga sebagai sumber radiasi yang memaparkan radiasi kepada sumsum merah yang merupakan sumsum tulang. Dalam proses metastasis, sumsum merah juga berperan mengumpulkan sel-sel tumor dari hampir semua jenis kanker, dan metastasis tulang terbentuk di hematopoietik sumsum merah aktif [23]. Dan dari Izotop (summary product characteristic) [24], dosimetri 99mTC-MDP produksi Institute of Isotope.Co.Ltd. berdasarkan ICRP 80th Internasional nilai dosis internal pasien untuk sumsum merah memiliki nilai tinggi ke-3 setelah dosis permukaan tulang. Software OLINDA/EXM yang digunakan tidak terdapat hasil permukaan tulang sehingga tidak didapatkan nilai dosis permukaan tulang.

Kemudian dosis yang terbesar kedua adalah sel osteogenik. Sel osteogenik tersebut terdapat di permukaan jaringan tulang pada periosteum bagian dalam dan juga endosteum. Sel osteogenik di permukaan luar akan membelah menjadi sel osteoblas (sel pembentukan tulang) sedangkan di dalam akan membentuk sel osteoklas (sel absorpsi dan degredasi tulang). Sel osteogenik berinteraksi dengan sel kanker berhubungan dalam penurunan aktivitas osteoblas dan peningkatan aktivitas osteoklas dan memicu proliferasi sel kanker [25].

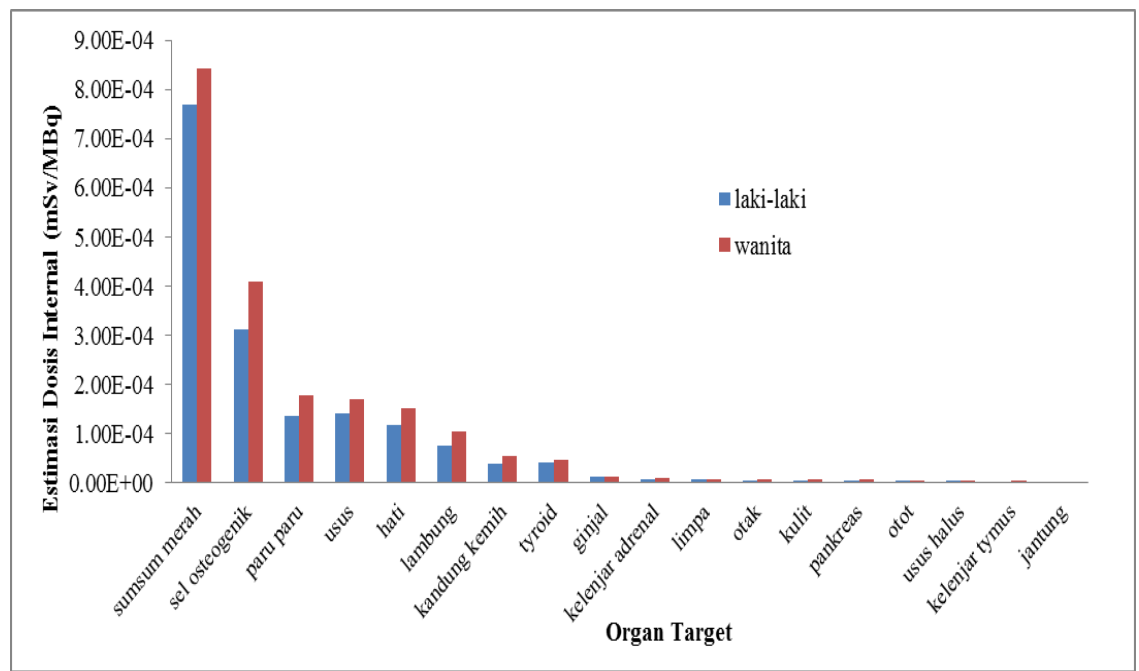

Gambar 4. Estimasi dosis internal organ manusia. 
Studi Awal Estimasi Dosis Internal 99mTc-MDP Hasil Produksi Pstnt-Batan Pada Manusia Untuk Deteksi Metastasis dan Inflamasi Tulang Berbasis Uji Biodistribusi Hewan Model Mencit (Isnaini Nur Islami, dkk.)

Tabel 2. Nilai dosis efektif 99mTc-MDP untuk tiap organ pada laki-laki dan wanita dewasa.

\begin{tabular}{lcc}
\hline \multirow{2}{*}{ organ target } & \multicolumn{2}{c}{ dosis efektif $(\mathrm{mSv} / \mathrm{MBq})$} \\
\cline { 2 - 3 } & laki-laki & wanita \\
\hline sumsum merah & $7,68 \times 10^{-4}$ & $8,42 \times 10^{-4}$ \\
Sel osteogenik & $3,12 \times 10^{-4}$ & $4,08 \times 10^{-4}$ \\
paru paru & $1,37 \times 10^{-4}$ & $1,77 \times 10^{-4}$ \\
usus & $1,41 \times 10^{-4}$ & $1,70 \times 10^{-4}$ \\
hati & $1,18 \times 10^{-4}$ & $1,51 \times 10^{-4}$ \\
lambung & $7,70 \times 10^{-5}$ & $1,04 \times 10^{-4}$ \\
kandung kemih & $3,94 \times 10^{-5}$ & $5,50 \times 10^{-5}$ \\
Kelenjar tiroid & $4,06 \times 10^{-5}$ & $4,57 \times 10^{-5}$ \\
ginjal & $1,16 \times 10^{-5}$ & $1,36 \times 10^{-5}$ \\
kelenjar adrenal & $7,29 \times 10^{-6}$ & $9,21 \times 10^{-6}$ \\
limpa & $6,21 \times 10^{-6}$ & $7,83 \times 10^{-6}$ \\
otak & $5,94 \times 10^{-6}$ & $7,14 \times 10^{-6}$ \\
kulit & $5,15 \times 10^{-6}$ & $6,51 \times 10^{-6}$ \\
pankreas & $5,15 \times 10^{-6}$ & $6,45 \times 10^{-6}$ \\
otot & $4,40 \times 10^{-6}$ & $5,44 \times 10^{-6}$ \\
usus halus & $3,66 \times 10^{-6}$ & $4,59 \times 10^{-6}$ \\
kelenjar timus & $2,94 \times 10^{-6}$ & $3,63 \times 10^{-6}$ \\
jantung & 0,00 & 0,00 \\
\hline
\end{tabular}

Distribusi dosis yang diperoleh merupakan dosis efektif dari masing-masing organ yang dapat berasal dari organ itu sendiri ataupun berasal dari organ terdekat lainnya. Sehingga, organ yang terkena paparan radiasi internal tersebut menjadi target bagi sumber radiasi lainnya, seperti kelenjar adrenal yang kemungkinan mendapatkan paparan radiasi dari ginjal [17].

Dalam penelitian ini digunakan mencit normal untuk estimasi dosis internal yang akan diterima manusia normal. Hal ini tetap bermanfaat karena metastasis tulang dalam aktivitas kumulatif metastasis akan lebih besar daripada tulang normal [26]. Maka dari hasil estimasi penelitian ini, dosis tulang normal didapatkan cukup besar sehingga jika diaplikasikan ke tulang metastasis akan lebih besar nilai dosisnya. Semakin tinggi nilai uptake pada organ maka terdapat kelainan pada organ tersebut [27]. Sehingka ketika distribusi aktivitas pada organ tulang normal tinggi maka distribusi aktivitas pada organ tulang pengidap metastasis ataupun inflamasi akan lebih tinggi dan pencitraan pada daerah tulang akan baik karena uptake radiofarmaka 99mTc-MDP tinggi di organ tulang.

\section{KESIMPULAN}

Dari penelitian ini didapatkan nilai estimasi dosis internal 99mTc-MDP produksi PSTNT berdasarkan uji biodistribusi pada hewan mencit normal menunjukkan bone scan menggunakan 99mTc-MDP memiliki sensitivitas yang tinggi terhadap tulang, sehingga radiofarmaka ${ }^{99 m T c-M D P}$ sangat baik dalam diagnostik tulang untuk bone staging. 
Jurnal Iptek Nuklir Ganendra

Ganendra Journal of Nuclear Science and Technology

Vol. 22 No. 2, Juli 2019: 85-93

\section{UCAPAN TERIMA KASIH}

Terima kasih kepada saudara Ahmad Sidiq, dr. Ahmad Kurniawan, dan Durotul Intokiyah yang telah membantu dalam pelaksanaan penelitian ini. Demikian juga kepada PSTNT BATAN Bandung dan PTKMR Jakarta yang telah memberikan fasilitas untuk melakukan penelitian ini.

\section{DAFTAR PUSTAKA}

[1] Kementrian Kesehatan RI, "Situasi Penyakit Kanker Indonesia," Pusat Data dan Informasi Kemenkes RI, no. 2, pp. 1-6, 2015.

[2] F. Safriadi, "Bone metastases and bone loss medical treatment in prostate cancer patients," Acta Med. Indones., vol. 45, no. 1, pp. 76-80, 2013.

[3] Ahmad Sulaiman Lubis \& Danarto, "Batasan Prostate Specific Antigen (PSA) pada Pasien Kanker Prostat untuk Memprediksi Metastasis ke Tulang di Rumah Sakit Sardjito, Yogyakarta," Indones. J. Cancer, vol. 8, no. 4, pp. 169-172, 2014.

[4] A. Briganti et al., "When to Perform Bone Scan in Patients with Newly Diagnosed Prostate Cancer: External Validation of the Currently Available Guidelines and Proposal of a Novel Risk Stratification Tool," Eur. Urol., vol. 57, no. 4, pp. 551-558, 2010.

[5] E. U. Hutagalung, "Metastatic bone disease," Med. J. Indones., vol. 13, no. 2, pp. 127-131, 2004.

[6] R. Suryanti, "Penentuan Dosis Internal Berbagai Organ Pada Pemeriksaan Bone Scan 99Tcm-MDP Dengan Metode MIRD," Universitas Indonesia, 2011.

[7] I. Fenta, D. Milvita, and F. Nazir, "Analisis Radiofarmaka Tc 99m MDP pada Pasien Kanker Payudara di Daerah Tulang Lutut dan Panggul," vol. 6, no. 2, pp. 132-138, 2017.

[8] V. J. Lewington, "Bone-seeking radionuclides for therapy," J. Nucl. Med., vol. 46, no. 1 SUPPL., pp. 38-48, 2005.

[9] R. J. Sugiharti, Y. Sumpena, and Misyetti, "COMPARISON OF 99mTc-CTMP AND 99mTc-MDP IN ANIMAL MODEL AS BONE IMAGING RADIOPHARMACEUTICAL," Indones. J. Nucl. Sci. Technol., vol. X, no. 2, pp. 89-96, 2009.

[10] M. G. Stabin, Fundamental of Nuclear Medicine Dosimetry. New York: Springer, 2008.

[11] M. M. Khalil, Basic Science of PET Imaging [Chapter title]. 2016.

[12] Z. Nurlaila, T. H. Basry, and R. Iljas, "Karakterisasi radiofarmaka sin sebagai penyidik infeksi Tc-siprofloksacals as the infection imaging," vol. 16, no. 4, pp. 214-221, 2005.

[13] Hassan Al-Jafar, M. AlFeeli, F. A. Alhaji, T. A. Abdullah, and E. Al-Shemmeri, "Bone Scintigraphy Scanning Safety and Necessity for Silent and Multifocal Osteonecrosis in Sickle Cell Disease," J. Hematol. Thromb., vol. 2, no. 1, pp. 1-4, 2016.

[14] B. H. Byun et al., "Comparison of (18)F-FDG PET/CT and (99 m)Tc-MDP bone scintigraphy for detection of bone metastasis in osteosarcoma," Skeletal Radiol., vol. 42, no. 12, pp. 1673-1681, 2013.

[15] S. Krüger et al., "Detection of bone metastases in patients with lung cancer: 99m Tc-MDP planar bone scintigraphy, 18 F-fluoride PET or 18 F-FDG PET/CT," Eur. J. Nucl. Med. Mol. Imaging, vol. 36, no. 11, pp. 1807-1812, 2009.

[16] A. L. Kesner, W. A. Hsueh, J. Czernin, H. Padgett, M. E. Phelps, and D. H. S. Silverman, "Radiation dose estimates for [18F]5-fluorouracil derived from PET-Based and tissue-based methods in rats," Mol. Imaging Biol., vol. 10, no. 6, pp. 341-348, 2008. 
Studi Awal Estimasi Dosis Internal 99mTc-MDP Hasil Produksi Pstnt-Batan Pada Manusia Untuk Deteksi Metastasis dan Inflamasi Tulang Berbasis Uji Biodistribusi Hewan Model Mencit (Isnaini Nur Islami, dkk.)

[17] N. R. Hidayati et al., "STUDI AWAL ESTIMASI DOSIS INTERNAL 177Lu-DOTA TRASTUZUMAB PADA MANUSIA BERBASIS UJI BIODISTRIBUSI PADA MENCIT," J. Sains dan Teknol. Nukl. Indones., vol. 16, no. 2, pp. 105-116, 2015.

[18] H. Rezaeejam, A. Hakimi, A. R. Jalilian, P. Abbasian, S. Shirvani-Aran, and M. Ghannadi-Maragheh, "Determination of human absorbed dose from [153Sm]-Samarium maltolate based on distribution data in rats," Int. J. Radiat. Res., vol. 13, no. 2, pp. 173-180, 2015.

[19] H. Ranjbar, A. Bahrami-Samani, M. R. Yazdani, and M. Ghannadi-Maragheh, "Determination of human absorbed dose of cocktail of $153 \mathrm{Sm} / 177 \mathrm{Lu}$-EDTMP, based on biodistribution data in rats," J. Radioanal. Nucl. Chem., vol. 307, no. 2, pp. 1439-1444, 2016.

[20] S. Shanehsazzadeh, A. Lahooti, S. P. Shirmardi, and M. Erfani, "Comparison of estimated human effective dose of $67 \mathrm{Ga}$ - and $99 \mathrm{mTc}$-labeled bombesin based on distribution data in mice," J. Radioanal. Nucl. Chem., vol. 305, no. 2, pp. 513-520, 2015.

[21] S. Christensen and O. W. Krogsgaard, "Localization of Tc-99m MDP in epiphyseal growth plates of rats," J. Nucl. Med., vol. 22, no. 3, pp. 237-245, 1981.

[22] E. Napitupulu and S. M. Sekarutami, "Metastasis Tulang: Patofisiologi," Radioter. Onkol. Indones., vol. 1, no. 2, pp. 59-66, 2010.

[23] M. Esposito, T. Guise, and Y. Kang, "The biology of bone metastasis," Cold Spring Harb. Perspect. Med., vol. 8, no. 6, 2018.

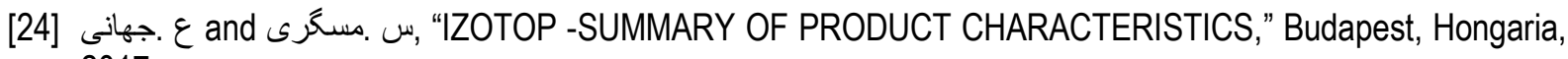
2017.

[25] A. B. Shupp, A. D. Kolb, D. Mukhopadhyay, and K. M. Bussard, "Cancer metastases to bone: Concepts, mechanisms, and interactions with bone osteoblasts," Cancers (Basel)., vol. 10, no. 6, pp. 1-37, 2018.

[26] H. Yousefnia, S. Zolghadri, and S. Shanehsazzadeh, "Estimated human absorbed dose of 177Lu-BPAMD based on mice data: Comparison with 177Lu-EDTMP," Appl. Radiat. Isot., vol. 104, pp. 128-135, 2015.

[27] W. Indriani, D. Milvita, F. Nazir, J. Fisika, and U. Andalas, "Uptake Radiofarmaka Tc 99m MDP pada Daerah Panggul dan Kepala dalam Menentukan Metastasis Tulang Pasien Kanker Prostat," vol. 6, no. 1, pp. 24-28, 2017. 